\title{
Potential distribution of Sphaeronycteris toxophyllum in Colombia and new record
}

\author{
Leidy Viviana García-Herrera ${ }^{1 *}$, Leidy Azucena Ramírez-Fráncel ${ }^{1}$ and Gladys Reinoso-Flórez ${ }^{2}$ \\ ${ }^{1}$ Ph. D. Student in Biological Sciences, Facultad de Ciencias, Grupo de investigación en Zoología, Universidad del Tolima, Colombia. Calle \\ \# 42, Santa Helena parte alta Ibagué-Tolima A.A. 546. Colombia. Email: Ivgarcia@ut.edu.co (LVGH), laramirezfr@ut.edu.co (LARF). \\ ${ }^{2}$ Facultad de Ciencias, Programa de Biología, Grupo de investigación en Zoología, Universidad del Tolima, Colombia. Calle \# 42, \\ Santa Helena parte alta Ibagué-Tolima A.A. 546. Colombia. E-mail: greinoso@ut.edu.co (GRF). \\ * Corresponding author
}

The visored bat, Sphaeronycteris toxophyllum Peters, 1882, is a species listed as Data Deficient by the International Union for the Conservation of Nature, being considered rare throughout its geographical range due to the small number of specimens recorded. This study reports a new record that broadens the distribution range of the species in Colombia to the central mountain range and upper valley of the Magdalena river. One adult male of S. toxophyllum was captured after a sampling effort of 3,870 net-hours over 36 nights in the Andean region, at the upper valley of the Magdalena river, Department of Tolima, Colombia. Its diet was analyzed and a model for Colombia was built. The morphometric analysis of the specimen captured yielded values lower than those previously reported for Colombia. The analysis of stomach contents identified two floristic elements as part of its diet, corroborating the frugivorous feeding habits of this species. Separately, the application of species distribution modeling techniques established that $S$. toxophyllum has a potential geographic range that continues north of the ChocóMagdalena province and west of the Orinoco and Guayana biogeographical provinces of Colombia. Based on these data, we propose that the extended distribution range reported here may be associated with a current connection between these geographical provinces.

El murciélago de vísera Sphaeronycteris toxophyllum Peters, 1882, está catalogado con Datos Deficientes por la Unión Internacional para la Conservación de la Naturaleza y es considerado raro a lo largo de su distribución, debido al escaso número de ejemplares conocidos. Este estudio presenta un nuevo registro que extienden la distribución geográfica de la especie en Colombia, hacia la cordillera Central y el valle alto del río Magdalena. Durante 36 noches y un esfuerzo de muestreo de 3,870 horas-red en la región andina en el valle alto del río Magdalena en el departamento de Tolima, Colombia, se capturó un macho adulto de S. toxophyllum. Se analizó su dieta y se construyó un modelo de distribución potencial para Colombia. El espécimen capturado registró medidas morfológicas craneales inferiores a las reportadas en trabajos previos para Colombia. El análisis del contenido estomacal permitió identificar dos elementos florísticos como parte de la dieta de la especie, información que permite corroborar su frugivoría. A través de la aplicación de técnicas de modelaje de distribución de especies fue posible establecer que S. toxophyllum presenta un intervalo geográfico potencial que se extiende al norte de la provincia Choco-Magdalena y al oeste de las provincias biogeográficas de la Orinoquia y de la Guayana de Colombia. Los datos permiten proponer que la ampliación de distribución presentada aquí puede estar asociada a la conexión existente entre estas provincias geográficas.

Key words: Chiroptera; distribution; geographic range; tropical dry forest; rare species.

(c) 2018 Asociación Mexicana de Mastozoología, www.mastozoologiamexicana.org

\section{Introduction}

Sphaeronycteris toxophyllum Peters, 1882, is one of the least known species of fruit bats in the Neotropics due to the small number of collections throughout its distribution range (Emmons and Feer 1990). The reported distribution includes Colombia (Sanborn 1941; Cuervo-Díaz et al. 1986; Gardner 2008; Rodríguez and Gonzales 2012); Bolivia (Koopman 1976; Anderson 1997); Brazil (Piccinini 1974; Peracchi 1986), Ecuador (Albuja and Mena 1991); Peru (Rehn 1901; Solari et al. 1998) and Venezuela (Thomas 1898; Handley 1976). It has been observed from the Amazon basin to 3,000 masl in secondary, cloud, and deciduous forests, as well as in open areas (Angulo et al. 2008). However, these are isolated records involving a few individuals.

In Colombia, the species has been recorded in the Departments of Amazonas (Rodríguez-Posada and Cárdenas-González 2012); Boyacá (Gallardo et al. 2014); Caquetá (Montenegro and Romero 1999); Casanare (RodríguezPosada and Cárdenas-González 2012); Cundinamarca
(Muñoz 2001; Solari et al. 2013); Guainía (Sanborn 1941); Magdalena (Cuervo-Díaz et al. 1986); Meta (RodríguezPosada and Cárdenas-González 2012); Norte de Santander (Sanborn 1941), Vaupés and Vichada (Rodríguez-Posada and Cárdenas-González 2012; Solari et al. 2013). These records correspond of a number of different natural regions of the country, including tropical humid forests, dry forests, montane forests, savannas and urban centers (RodríguezPosada and Cárdenas-González 2012).

Despite the broad distribution of S. toxophyllum according with the International Union for the Conservation of Nature (IUCN 2018), it is classified as Deficient Data and there is concern that this status may shift to Near Threatened in the future. The distribution range reported for this species comprises the Central mountain range in the upper valley of the Magdalena river and the Tropical Dry Forest (BST) of Colombia, a highly fragile and threatened ecosystem. This study discusses the rarity of S. toxophyllum based on existing records, as well as its potential distribution area. 
It incorporates the first dietary records of the species for BST, filling previous information gaps.

\section{Materials and Methods}

Sampling was carried out in 2014 to assess the trophic structure of the bat fauna at Centro Universitario Regional del Norte, located in the upper valley of the Magdalena river, in the municipality of Armero Guayabal, Department of Tolima, Colombia ( $5^{\circ} 0^{\prime} 21.49^{\prime \prime} \mathrm{N},-74^{\circ} 54^{\prime} 28.42^{\prime \prime} \mathrm{W}$; Figure 1). This locality has an altitude of 240 masl, with a mean annual temperature of $28{ }^{\circ} \mathrm{C}$, and a precipitation of 1,791 mm (CORTOLIMA 2007).

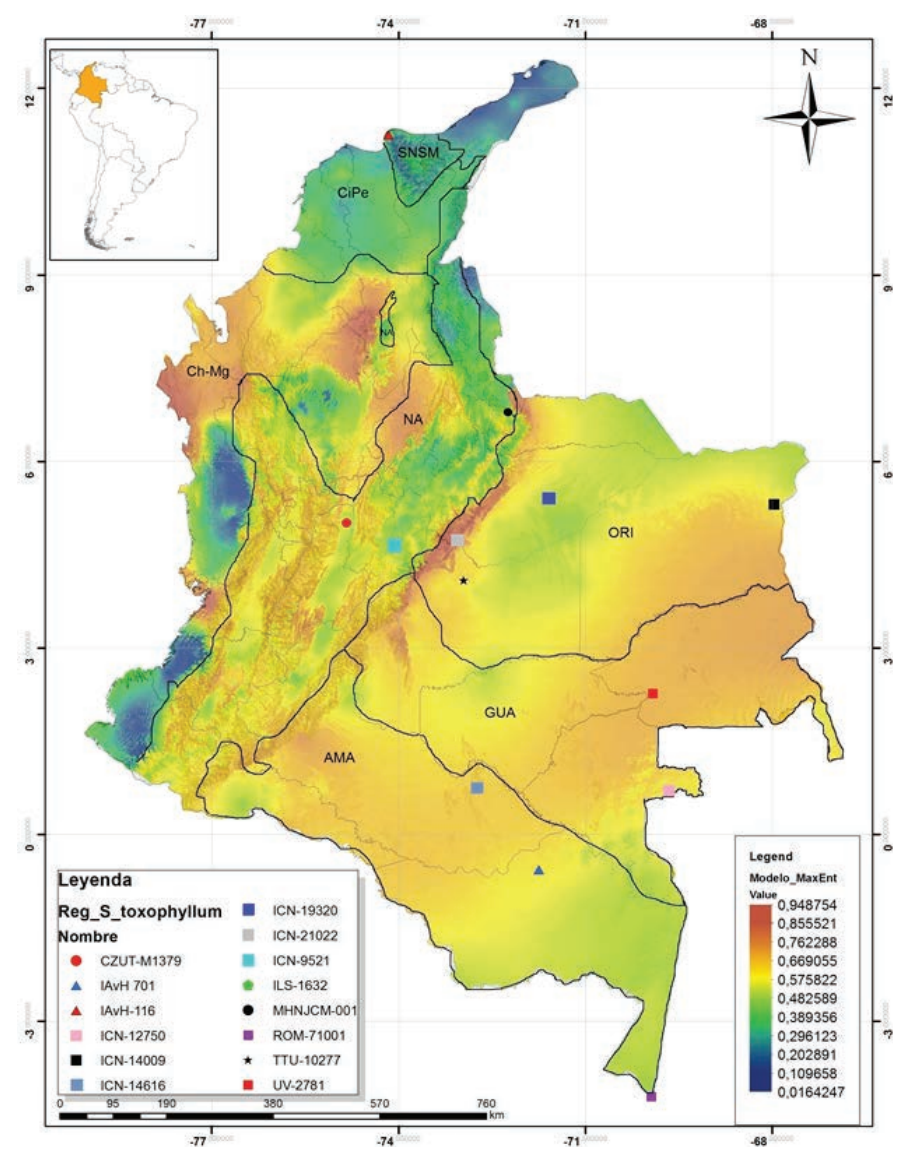

Figure 1. Model of potential distribution of Sphaeronycteris toxophyllum in Colombia and records in the collection of mammals of the Instituto de Ciencias Naturales at Universidad Nacional de Colombia ICN (squares), Instituto de Investigación de Recursos Biológicos Alexander von Humboldt IAVH (triangles), Museo La Salle ILS (pentagon), Museo de Historia Natural José Celestino Mutis at the Universidad de Pamplona MHNJCM (black circle), Royal Ontario Museum ROM (purple square), Texas Tech University TTU (star), collection of mammals of the Universidad del Valle UV (red square) and a new locality reported of the Zoological Collection at Universidad del Tolima CZUT (red circle). Black lines show the boundaries of biogeographical regions according to Hernández-Camacho et al. (1992); CiPe, peri-Caribbean arid belt; SNSM, Sierra Nevada de Santa Marta; Ch-Mg, Chocó-Magdalena; NA, North-Andean; ORI, Orinoco; GUA, Guayana; AMA, Amazon.

One adult male of S. toxophyllum was captured after a sampling that involved six mist nets measuring $6 \times 2.5 \mathrm{~m}$ and three measuring $12 \times 2.5 \mathrm{~m}$, with a sampling effort of 3,870 net-hours over 36 nights. The specimen captured was handled according to the recommendations of the American Society of Mammalogists (Sikes et al. 2011) regarding capture and handling procedures. A series of standard morphometric measurements (Simmons and Voss 1998) of this specimen were determined with a Mitutoyo gauge accurate to $0.1 \mathrm{~mm}$ (Table 1), and the weight was measured with an electronic scale accurate to $0.1 \mathrm{~g}$. Age was estimated based on the degree of ossification of epiphyseal growth plates of finger phalanges (Dietz et al. 2009), and the reproductive condition was determined according to Kunz et al. (1996).

The individual was identified using the taxonomic keys proposed by Gardner (2008). It was preserved in skin and skull in the Zoological Collection of Universidad de Tolima, Mammalogy Section, under catalog number CZUT-M 1,379.

A distribution model was elaborated for S. toxophyllum from 14 presence records in various regions of Colombia, in the Departments of Amazonas, Boyacá, Casanare, Caquetá, Cundinamarca, Magdalena, Meta, Norte de Santander, Tolima, Vaupes and Vichada; provisions were taken to ensure that data be obtained from reliable information sources: scientific literature and biological collections (Table 2). Each individual datum was recorded systematically, including geo-referenced information (latitude and longitude), Department, and locality. The information was screened using the Google Earth Pro application to determine the geographical location of each individual record; only properly georeferenced data were used.

The potential habitat of S. toxophyllum was modeled using the software Maxent v3.4.1. This program determines the relationship between climatic variables and records of the species (Guisan and Thuiller 2005), and assumes that the climate in the observation points of a species represents its environmental range; therefore, climate was used as a model predictor (Jarvis et al. 2005). We used historical values of 19 climatic variables (Table 3) from the global database WorldClim version 2 (http:// worldclim.org) accessed on 23 June 2018. The model was evaluated statistically by analyzing the area under the curve (AUC), which ranges from 0 to 1 ; values close to 1 indicate has good performance of the model, while values near or below 0.5 indicate that the model has no predictive power (Guisan and Thuiller 2005).

Table 1. External and cranial measurements of the male of Sphaeronycteris toxophyllum from Armero Guayabal, Department of Tolima (Tolima), data from a male by Rodriguez and Gonzales (2012; RyG) and a females form Gallardo et al. (2014) mesaurementes in milimeters (min. - max.)

\begin{tabular}{lrcr} 
Variables & Tolima & $\begin{array}{c}\text { Rodríguez y } \\
\text { Gonzales }\end{array}$ & $\begin{array}{c}\text { Gallardo } \\
\text { et al. }\end{array}$ \\
\hline Total length & 53.64 & $47.70-54.00$ & 54.00 \\
Forearm length & 37.67 & $37.00-38.07$ & 38.00 \\
Tibia length & 15.27 & $16.90-18.76$ & 16.80 \\
Ear length & 8.25 & $8.85-15.00$ & 11.20 \\
Maximum skull length & 15.76 & $15.80-16.14$ & 16.50 \\
Condyle-incisive length & 12.47 & $14.16-14.47$ & 14.46 \\
Condyle-canine length & 12.09 & $13.59-14.22$ & 14.12 \\
Postorbital width & 5.23 & $5.29-5.78$ & 5.94 \\
Zygomatic width & 11.63 & $11.74-12.07$ & 11.40 \\
Skull width & 8.15 & $8.76-9.10$ & 9.60 \\
Mastoid width & 9.33 & $9.94-10.12$ & 10.12 \\
Length of maxillary tooth row & 4.35 & $4.37-4.56$ & 4.45 \\
\hline
\end{tabular}




\section{Results}

The presence of $S$. toxophyllum in the central mountain range of Colombia is reported herein for the first time. This record is based on a single specimen collected in the northern portion of the Department of Tolima, in the upper valley of the Magdalena river. This record broadens the known distribution of $S$. toxophyllum to approximately 110 $\mathrm{km}$ west of the nearest known locality in the Department of Cundinamarca (ICN- 9521, Figure 1).

The collection locality shows vegetation elements typical of Tropical Dry Forest (BST), with predominance of clayey, silt-clayey and loamy soils, with trees measuring less than $8 \mathrm{~m}$ in height and shrubs up to $3 \mathrm{~m}$ in height. Some areas show vegetation in early successional stages, such as Acacia farnesiana, Acalypha macrostachya, Calliandra pittier, Cecropia peltata, Centrosema pubescens, Cordia alliodora, Crataeva tapia, Crotalaria incana, Croton schiedeanus, Cnidoscolus urens, Chiococca alba, Henriettella fissanthera, Maclura tinctoria, Melochia pyramidata, Mimosa pigra, Myrtus communis, Piper aduncum, Piper bogotense, Pithecellobium dulce, Sapium glandulosum, Solanum betaceum, Solanum nigrum, Solanum quitoense, Tabernaemontana grandiflora and Vernonanthura brasiliana.

The specimen of S. toxophyllum collected has all of the diagnostic characters of the species (Husson 1958; Emmons and Feer 1997; Gardner 2008; Angulo et al. 2008). However, the majority of its morphological measures are smaller than those reported previously (Table 1; Gallardo et al. 2014; Rodríguez-Posada and Cárdenas-González 2012). The specimen has long and tri-color pelage: dorsum brown to dark brown with a grayish shade and individual hairs whitish in the center of the dorsum, white spot on the shoulder near the wing; anterior part lighter than the posterior, and abdomen brown.

Rostrum short, less than half the braincase length; nasal and maxillary bones projected upwards, oriented vertically

Table 2. Records of the Colombian localities with records of S. toxophyllum used for the model of potential distribution of the species. *New record.

\begin{tabular}{llrc}
\hline Acronym & Locality & Latitude & Longitude \\
\hline IAvH 701 & Amazonia, corregimiento La Chorrera & -0.56663 & -71.74994 \\
ROM 71001 & Amazonia, Leticia & -3.78472 & -69.94056 \\
MHNJCM-001 & Boyacá, Cubará & 7.04716 & -72.16939 \\
ICN- 9521 & Bogotá, Ciudad universitaria. & 4.64360 & -74.14406 \\
ICN- 21022 & Casanare, San Jorge trail & 4.72086 & -73.04997 \\
ICN- 19320 & Casanare, El Banco de la Cañada trail & 5.41661 & -71.59850 \\
ICN 14616 & Caquetá & 0.74737 & -72.73729 \\
UV 2781 & Guainía, corregimiento Morichal & 2.26370 & -69.91847 \\
IAvH 116 & Magdalena, Sierra Nevada de Santa Marta & 11.25000 & -74.16339 \\
TTU 10277 & Meta, municipality of Puerto López & 4.08500 & -72.95528 \\
ILS 1632 & Norte de Santander, municipality of Pamplona & 7.37093 & -72.65237 \\
CZUT-M 1379* & Tolima, municipality of Armero Guayabal & 4.64360 & -74.14406 \\
ICN 12750 & Vaupés, municipality of Taraira & 0.56474 & -69.63411 \\
ICN 14009 & Vichada, Tuparro Natural National Park & 5.30750 & -67.97128 \\
\hline
\end{tabular}

in the same plane as the palatine process; nasal opening located at the base of the skull, which resembles a primate in lateral view; anterior margin of the orbit extends to form a conspicuous plate; palatal emargination V-shaped, shallow and extended approximately to half of second upper molar (Figure 2).

The analysis of the stomach contents of $S$. toxophyllum revealed $70 \%$ plant cell tissue (pulp) and $30 \%$ seeds, belonging to Chiococca alba $(n=7 ; 23.1 \%)$ and Henriettella fissanthera $(n=2 ; 6.6 \%)$. The following taxa were reported together with the capture of S. toxophyllum: Emballonurinae: Saccopteryx bilineata, S. leptura. Phyllostomidae: Carollia brevicauda, C. perspicillata, Desmodus rotundus, Glossophaga soricina, Phyllostomus discolor, P. hastatus, Trachops cirrhosus, Artibeus lituratus, A. planirostris trinitatis, Dermanura phaeotis, Mesophylla maconnelli, Platyrrhinus helleri, Uroderma convexum. Vespertilionidae: Eptesicus brasiliensis, Myotis nigricans, M. riparius, Rhogeessa io. Molossidae: Molossus molossus.

The distribution model for S. toxophyllum yielded an average AUC of 0.94 (range: 0.926-0.949), indicating a good performance with low levels of commission errors and identifying all the localities where the species has been reported (Figure 1). The empirical evaluation allows establishing the usefulness and efficiency of the model to find potential sites of occurrence of the species.

The model predicts a distribution in four of the nine biogeographical provinces proposed for Colombia by Hernández-Camacho et al. (1992). The highest probability of occurrence is recorded in the northern part of the ChocóMagdalena biogeographical provinces in the Departments of Antioquia, Chocó, southern Bolivar and Sucre, and east of

Table 3. Climatic variables used in the program MaxEnt to produce the map of potential distribution of S. toxophyllum for Colombia.

\footnotetext{
Climatic Variables

1. Mean annual temperature $\left({ }^{\circ} \mathrm{C}\right)$

2. Diurnal temperature variation $\left({ }^{\circ} \mathrm{C}\right)$

3. Isothermality (ratio between parameters 2 and 7)

4. Temperature seasonality (coefficient of variation \%)

5. Mean maximum temperature of the warmest season $\left({ }^{\circ} \mathrm{C}\right)$

6. Mean minimum temperature of the coldest season $\left({ }^{\circ} \mathrm{C}\right)$

7. Annual temperature variation (difference between parameters 5 and 6)

8. Mean temperature of the rainiest four-month period $\left({ }^{\circ} \mathrm{C}\right)$

9. Mean temperature of the driest four-month period $\left({ }^{\circ} \mathrm{C}\right)$

10. Mean temperature of the warmest four-month period $\left({ }^{\circ} \mathrm{C}\right)$

11. Mean temperature of the coldest four-month period $\left({ }^{\circ} \mathrm{C}\right)$

12. Annual precipitation $(\mathrm{mm})$

13. Precipitation of the rainiest period $(\mathrm{mm})$

14. Precipitation of the driest period $(\mathrm{mm})$

15. Precipitation seasonality (coefficient of variation \%)

16. Precipitation of the rainiest four-month period $(\mathrm{mm})$

17. Precipitation of the driest four-month period $(\mathrm{mm})$

18. Precipitation of the warmest four-month period $(\mathrm{mm})$

19. Precipitation of the coldest four-month period ( $\mathrm{mm}$ )
} 


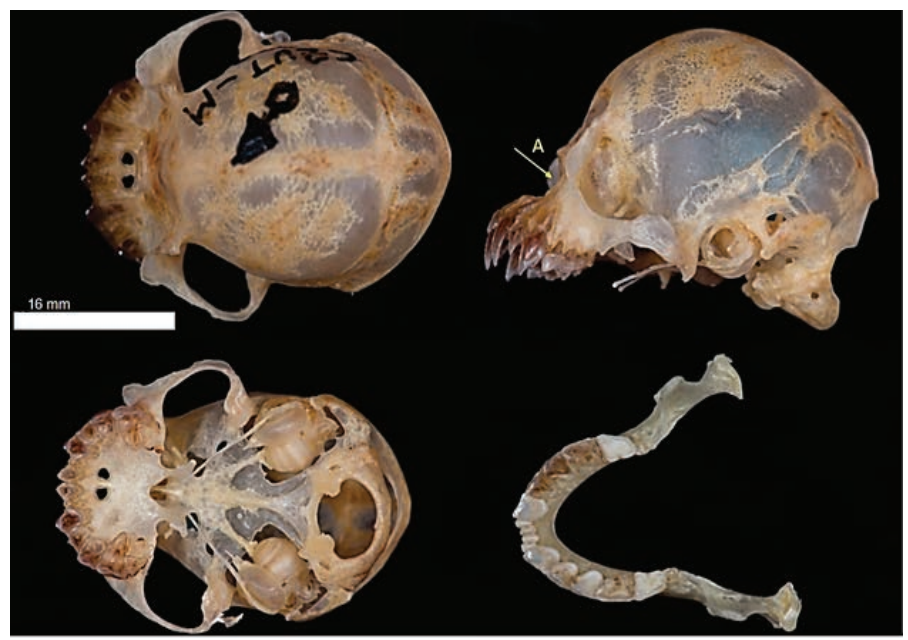

Figure 2. Dorsal, ventral and side view of skull and jaw of Sphaeronycteris toxophyllum (CZUT-M 1379) male from Armero Guayabal, Department of Tolima, Colombia. A) nasal and maxillary projected upwards with nasal openings at the base of the skull.

Córdoba; west of the Orinoco biogeographical province in the Departments of Arauca and Casanare, and north of the biogeographical province of Guayana in the Department of Meta, the northwestern zone of the North Andean biogeographical province in the Department of Santander; the rest of the latter province records a medium-to-low probability of occurrence of this species.

The annual temperature range was the variable that contributed more information to the model when used individually, being the one containing the greatest amount of information, unlike any other variable. In general, the variables that contributed most information to the distribution model of $S$. toxophyllum are those related to temperature (temperature seasonality and isothermality).

\section{Discussion}

The available information on S. toxophyllum in Colombia reveals its distribution in contrasting environments. To date, however, there were no records of its presence in the Cordillera Central, nor in the inter-Andean valleys of the Magdalena and Cauca rivers. The existing records of the species correspond to very dry forests, as those that cover the northwestern portion of the North-Andean biogeographical province in northern Santander (Sanborn 1941), as well as in humid tropical forests, in Boyacá (Gallardo et al. 2014). These latter authors reported the presence of the species in the boundary between Cundinamarca and Tolima corresponding to the specimen with voucher ID ICNMastozoologia 9521. However, the review of the information provided revealed that this is a wrong location on the distribution map, as the report was gathered in the locality Ciudad Universitaria, Department of Cundinamarca, Bogotá D. C., 11 September 1986; this specimen is deposited in the "Alberto Cadena García" mammal collection of the Institute of Natural Sciences at the National University of Colombia.

To note, the record reported here not only represents the first report of the species for the Central Cordillera, but also implies an extension of the ecological range, for being located in a region with environmental and climatic characteristics that differ from those that characterize the Eastern Cordillera, where the closest previous record is located (Cundinamarca, ICN-9521).

The analysis of the stomach contents of S. toxophyllum revealed the presence of two plant elements that are the first evidence of the diet of this species and confirm its frugivorous status. However, the limited number of samples analyzed restrain a reliable determination of its feeding habits, but nonetheless contributes information to the diet of this species by filling information gaps, at least for the BST biome.

The modelled distribution of S. toxophyllum comprises the northern Chocó-Magdalena, western Orinoco, and northern Guayana biogeographical provinces. The analysis of the available information suggests that this distribution and the average probability of occurrence of this species in the north-Andean biogeographical province (particularly in the central Cordillera) is established by the ecological association between the Chocó region and the valleys of the Magdalena and Cauca rivers, being a zone where the biological elements of these areas are exchanged with CisAndean elements and those from the Magdalena valley, using the Orinoco foothills as a biological corridor, crossing the Burbúa depression, and reaching the Catatumbo basin (Hernández-Camacho et al. 1992). The species studied may occur along the Magdalena dry areas and the Orinoco and Guayana provinces.

The model does not predict the presence of S. toxophyllum in the Macizo de la Sierra Nevada de Santa Marta, despite the fact that Cuervo-Díaz et al. (1986) report its presence in this locality. It is worth noting that many of the biological elements in this area derive from lowlands of Andean origin, and move with relative ease toward the Serranía del Perijá, since a considerable number of common plant and animal species have been established in both of these formations (Hernández-Camacho et al. 1992).

Likewise, the model does not predict the presence of this species in the Amazon biogeographical province; however, Rodriguez-Posada and Cárdenas-González (2012) and Montenegro and Romero (1999) have reported its presence in the Departments of Amazonas and Caquetá, this being the southernmost distribution known in Colombia. Also, the model does not predict the presence of S. toxophyllum in the northern area of the Department of Tolima, a record reported herein.

The model of potential distribution of S. toxophyllum for Colombia carried out in this study contrasts with the model proposed for this same species by Angulo et al. (2008), who reported that part of the Department of La Guajira and the north-Andean biogeographical province and the totality of the Orinoco, Guayana and Amazon biogeographical provinces are highly suitable for the presence of the species. It should be stressed that the potential model proposed by Angulo et al. (2008) was designed for all South America. However, an aspect to bear in mind is that different meth- 
ods lead to different results. Furthermore. the distribution model presented here takes into account only the relationship with climate and does not consider the presence of geographic barriers, ecological interactions or habitat requirements, all of them aspects that might also influence the distribution of the species.

The application of distribution modeling techniques showed that S. toxophyllum probably has a continuous potential geographical range from the northern Chocó-Magdalena to the western Orinoco provinces. Temperature was determined to be the climate variable with the greatest influence on the occurrence of this species, a fact that supports conservation strategies not only for these areas, but also for the biotic elements that govern temperature changes.

\section{Acknowledgments}

The authors would like $t$ o thank the Central Committee for Research at the University of Tolima for research funding that allowed the capture of the specimen reported. Thanks also to field assistants (K. Gutierrez and K. Fonseca), to officials at Centro Universitario Regional del Norte, and to A. Torres for the technical support in vegetation sampling. María Elena Sánchez-Salazar translated the manuscript into English.

\section{Cited literature}

Albuja, V. L., And P. V. Mena. 1991. Adición de dos especies de quirópteros a la fauna del Ecuador. Politécnica 16:93-98.

Anderson, S. 1997. Mammals of Bolivia, Taxonomy and Distribution. Bulletin of the American Museum of Natural History 231:652.

Angulo, S. R., J. A. Ríos, And M. M. Díaz. 2008. Sphaeronycteris toxophyllum (Chiroptera: Phyllostomidae). Mammalian Species 814:1-6.

Corporación Autónoma Regional del tolima (CORTOlima). 2007. Planes de Ordenamiento y manejo de las cuencas hidrográficas. Ibagué, Colombia.

Cuervo-Díaz, C. A., J. Hernández, and A. Cadena. 1986. Lista actualizada de los mamíferos de Colombia: anotaciones sobre su distribución. Caldasia 15:471-501.

Dietz, C., O. Von Helversen, and D. Nill. 2009. Bats of Britain, Europe \& Northerwest Africa. A\&C Black. London.

Emmons, L. H., ANd F. Feer. 1990. Neotropical Rainforest Mammals: A field guide. The University of Chicago Press. Chicago, U. S. A. Emmons, L. H., ANd F. Feer. 1997. Neotropical Rainforest Mammals, a Field Guide. 2da edition. The University of Chicago Press. Chicago, U.S. A.

Gallardo, A. O., L. Peña, O. Armesto, and J. Sequeda. 2014. First record of Sphaeronycteris toxophyllum Peters, 1882 (Chiroptera: Phyllostomidae) for the Department of Boyacá, Eastern Cordillera of Colombia. Check List 10:97-699.

Gardner, A. L. 2008. Tribe Stenodermatini. Pp. 361-363 in Mammals of South America Marsupials, Xenarthrans, Shrews and Bats (Gardner A. L. ed.). The University of Chicago Press. Chicago, U. S. A.

GUISAN, A., ANDW.THUILER. 2005. Predicting species distribution: offering more than simple habitat models. Ecology Letters 8:993-1009
HANDLEY, C.O. 1976. Mammals of the Smithsonian Venezuelan Project. Brigham Young University Science Bulletin. Biological Series 20:1-91.

Hernández-Camacho, J., T. Walschburguer, R. Ortiz, and A. Hurtado. 1992. Origen y distribución de la biota suramericana y colombiana. Pp. 55-104 in La diversidad biológica de Iberoamérica I (Halffer, G. ed.). Acta Zoológica Mexicana. Volumen especial. CYTED-D. Programa Iberoamericano de Ciencia y Tecnología para el Desarrollo. México.

Husson, A. M. 1958. Notes on the neotropical leaf-nosed bat Sphaeronycteris toxophyllum Peters. Archives Neerlandaises de Zoologie 13:114-119.

Jarvis, A., K. Williams, D. Williams, L. Guarino, P. J. Caballero, and G. MotTram. 2005. Use of GIS for optimizing a collecting mission for a rare wild pepper (Capsicum flexuosum Sendtn) in Paraguay. Genetic Resources and Crop Evolution 2:671-682.

Koopman, K. F. 1976. Zoogeografía. Pp. 39-47 in Biology of bats of the New World Family Phyllostomidae (Baker, R. J., J. K. Jones, J r., and D. C. Carter, eds.). Special Publications of the Museum of Texas Tech University 10:1-218.

Kunz, T.H. 1996. Methods of marking bats. Pp. 304-310 in Measuring and monitoring biological diversity standard methods for mammals. Smithsonian Institution (Wilson, D. E. J. Nichols, R. Rudrin, R. Cole, and M. Foster, eds.). Washington, U. S. A.

Montenegro, O., And M. R. Romero. 1999. Murciélagos del sector sur de la Serranía de Chiribiquete, Caquetá, Colombia. Revista de la Academia Colombiana de Ciencias 23:641-649.

MuÑoz, J. 2001. Los murciélagos de Colombia. Sistemática, distribución, historia natural y ecología. Editorial Universidad de Antioquia. Medellín, Colombia.

PerACCHI, A. L. 1986. Considerações sobre a distribuição e a localidade-tipo de Sphaeronycteris toxophyllum Peters,1882 (Chiroptera, Phyllostomidae). Publicacoes Avulsas Museu Nacional Rio de Janeiro 65:97-100.

PıcCININI, R. S. 1974. Lista provisoria dos quirópteros da Coleção do Museu Paraense Emílio Goeldi (Chiroptera). Boletim do Museu Paraense Emílio Goeldi, Série Zoologia 77:1-32.

ReHN, J. A. 1901. Notes on Chiroptera. Proceedings of the Academy of Natural Sciences of Philadelphia 1900:755-759.

Rodríguez, M. E., And C. A. González. 2012. El Murciélago de Visera Sphaeronycteris toxophyllum Peters, 1882 (Chiroptera: Phyllostomidae) en Colombia. Chiroptera Neotropical 18:1115-1122.

SAnBorn, C. C. 1941. Descriptions and records on Neotropical bats. Field Museum of Natural History 27:321-387.

Sikes, R. S., W. H. Gannon, and the Animal Care and Use Committee of the American Society of Mammalogists. 2011. Guidelines of the American Society of Mammalogists for the use of wild mammals in research and education. Journal of Mammalogy 97:663-688. Simmons, N. B., AND R. S. Voss. 1998. The mammals of Paracou, French Guiana: A Neotropical lowland rainforest fauna. Bulletin of the American Museum of Natural History 237:1-219.

Solari, S., E. Vivar, J. J. Rodríguez, and J. L. Mena. 1998. Pequeños mamíferos: evaluación de la biodiversidad en la región baja de Urubamba. Pp. 209-218 in Evaluación de la biodiversidad y monitoreo de la región baja de Urubamba, Perú: sitio de pozo Cashiriari-3 y los ríos Camisea y Urubamba (Alonso, A., and F. Dallmeier, eds.). Serie SI / SIMAB \# 2, Institución Smithsonian, Programa de Biodiversidad del MAB, Washington, DC. 
Solari, S., Y. Muñoz-Saba, J. V. Rodríguez-Mahecha, T. R. Defler, H. E. Ramírez-Chaves, and F. Trujillo. 2013. Riqueza, endemismo y conservación de los mamíferos de Colombia. Mastozoología Neotropical 20:301-365.

Thomas, O. 1898. On seven new small mammals from Ecuador and Venezuela. Annals and Magazine of Natural History 7:451-57.

UICN. 2018. Unión Internacional para la Conservación de la Naturaleza. http://dx.doi.org/10.2305/IUCN.UK.2008.RLTS. T20599A9213038. Consultado el 12 de julio de 2018.

Associated editor: Robert Owen

Submitted: April 24, 2017; Reviewed: June 4, 2018;

Accepted: July 18, 2018; Published on line: August 20, 2018. 